\title{
SISTEM PENDUKUNG KEPUTUSAN PEMBERIAN REWARD PENYIAR RADIO DENGAN METODE MULTIFACTOR EVALUATION PROCESS
}

\author{
Andrew Kurniawan Vadreas ${ }^{1}$, Dwi Welly Sukma Nirad ${ }^{2}$, Meyzi Rosiana ${ }^{3}$ \\ ${ }^{1}$ Program Studi Sistem Informasi, STMIK Indonesia Padang \\ email: andrewvadreas@stmikindonesia.ac.id \\ ${ }^{2}$ Program Studi Sistem Informasi, Universitas Andalas \\ email: dwiwellysukmanirad@it.unand.ac.id \\ ${ }^{3}$ Program Studi Sistem Informasi, STMIK Indonesia Padang \\ email: roshianameizy25@gmail.com
}

\begin{abstract}
Abstrak
Radio merupakan salah satu sarana informasi dan hiburan bagi masyarakat yang biasanya di dengarkan di sela-sela aktivitas. Penyiar radio menjadi salah satu unsur penting dalam suatu radio sangat menentukan penyampaian informasi maupun hiburan kepada pendengar. Untuk itu dibutuhkan sebuah support kepada penyiar agar selalu optimal dalam kerjanya, sehingga pendegar radio semakin banyak. Reward ataupun pembinaan keahlian dan ketrampilan dapat menjadi motivasi ataupun penghargaan bagi kerja penyiar. Oleh Karena itu perlu adanya suatu sistem yang membantu kerja program director dalam memilih seorang penyiar radio yang dapat dikategorikan sebagai penyiar radio yang berhak menerima reward berdasarkan kriteria-kriteria yang ada. Dari permasalahan tersebut maka dibuatlah sistem yang dapat mengakomodir semua faktor kriteria. Perhitungan penilaian kriteria menggunakan metode MFEP ini disebabkan karena pendekatan MFEP (Multi Factor Evaluation Process) ini dapat bekerja pada situasi yang kompleks dan memungkinkan untuk melakukan suatu analisa dengan data yang minimum. Hasil atau keluaran berupa report atau laporan nilai untuk penyiar radio yang berhak menerima reward berdasarkan kriteria maupun sub kriteria yang telah ditentukan.
\end{abstract}

Keywords: Radio, Sistem pendukung keputusan, Reward, MFEP (Multi Factor Evaluation Process)

\begin{abstract}
Radio is one of the means of information and entertainment for people who are usually listened to on the sidelines of activities. Radio broadcasters are one of the important elements in a radio that determines the delivery of information and entertainment to listeners. For that, we need the broadcasters so that they are always optimal in their work so that there are more radio listeners. Reward or coaching expertise and skills can be a motivation or appreciation for the work of broadcasters. Therefore, it is necessary to have a system that helps the program director work in selecting a radio broadcaster who can be categorized as a radio broadcaster who is entitled to receive rewards based on existing criteria. From these problems, a system is made that can accommodate all the criteria factors. The calculation of the criteria assessment using the MFEP method is because the MFEP (Multi Factors Evaluation Process) approach can work in complex situations and allows for analysis with minimum data. The results or outputs are in the form of reports or value reports for radio broadcasters who are entitled to receive rewards based on predetermined criteria or sub-criteria.
\end{abstract}

Keywords: Radio, decision support system, reward, MFEP (Multi Factor Evaluation Process)

\section{PENDAHULUAN}

PT Radio Kiara Indah Berjaya yang menjadi studi kasus dalam penelitian ini. PT Radio Kiara Indah Berjaya atau lebih dikenal Radio Kiara 96,7 Fm adalah salah satu radio swasta yang didirikan pada 17 April 2005 yang terletak di jl. Raya Lubuk Begalung no.6 Padang, Sumatera Barat. Setiap radio mempunyai frekuensi sendiri begitu juga dengan PT. Radio 
Kiara Indah Berjaya atau biasa disebut denga radio Kiara dengan frekuensi 96,7 Fm. Radio kiara sama halnya dengan radio-radio lainnya yang menyuguhkan informasi, hiburan dan lain-lainnya. Sebuah radio tentunya memiliki penyiar (Radio Announcer) yang bertugas memperkenalkan dan membahas berbagai hal seperti musik, mengadakan wawancara yang turut melibatkan pendengar, menyampaikan berita, ramalan cuaca, perkembangan olahraga, informasi terkini, lalu lintas dan lain-lain.

Sebagai penyiar radio tentunya mereka juga berhak mendapatkan upah, gaji atau penghasilan. Gaji penyiar radio dihitung berdasarkan jumlah jam siaran dalam sebulan yang dilihat dari laporan presensinya, masa kerja, serta insentif sebagai kompensasi dari kinerjanya. Salah satu jenis kompensasi lainnya adalah reward atau bonus, yakni imbalan berbentuk uang atau hal lain yang diberikan kepada karyawan sebagai apresiasi kerja dan prestasi.

Dalam penelitian ini akan meneliti penyiar radio kiara 96,7 Fm terutama dalam pemberian reward atau bonus bagi penyiar yang memiliki kinerja yang memuaskan. Pemberian bonus/reward merupakan salah satu metode yang banyak digunakan oleh perusahaan sebagai sebuah bentuk penghargaan kepada pekerja yang kinerjanya selama ini dapat dianggap memuaskan bagi perusahaan (Rachmat Agusli1, Muhammad Iqbal Dzulhaq2 2017). Dengan adanya pemberian bonus/ reward ini dapat meningkatkat semangat penyiar dalam siaran dan menarik perhatian pendengar. Karena bagi penyiar kepuasan pendengar terhadap mereka juga mempengaruhi penilaian terhadap pemberian bonus/ reward tersebut diukur dari : 1) Cara pemilihan kata saat siaran, 2) Penyampaian informasi, 3) Sikap/ perilaku, 4) Kedisiplinan penyiar dalam bersiaran seperti ketepatan waktu siar, dan

5) Mengetahui penyiar yang memiliki pendengar terbanyak setiap kali bersiaran.
Bagi perusahaan yang bergerak di bidang informasi dan hiburan seperti radio Kiara 96,7 FM untuk memilih penyiar radio yang berhak menerima reward atau bonus tidaklah mudah, karena dalam proses pemilihan memiliki kriteriakriteria tertentu yang perlu diperhatikan. Untuk itu seorang pimpinan dalam Perhitungan penilaian terhadap kriteria harus benar-benar relevan karena pada dasarnya akan berpengaruh pada hasil akhirnya (Yunitarini 2013). Adapun permasalahan yang ada saat ini biasanya dalam menentukan atau menyeleksi penyiar yang menerima reward atau bonus dilakukan dengan cara memantau setiap kinerja penyiar yang dinilai kurang efektif, selain itu belum adanya suatu sistem pendukung keputusan yang di gunakan dalam pemberian reward atau bonus pada penyiar. Pemilihan penyiar yang layak mendapatkan bonus/ reward dan banyaknya jumlah penyiar, tentunya memberikan pekerjaan yang berlebih bagi Program Directur PT. Radio Kiara Indah Berjaya untuk memilih secara manual penyiar yang berhak menerima bonus/ reward dari perusahaan. Untuk itu diperlukan suatu sistem pendukung keputusan (SPK) yang dapat memperhitungkan segala kriteria yang mendukung pengambilan keputusan guna membantu mempermudah proses pengambilan keputusan dengan tepat (Yanto 2021).

Beberapa penelitian sebelumnya yang terkait dalam penelitian ini mengatakan bahwa dalam menentukan kenaikan gaji karyawan suatu perusahan dapat dilakukan dengan menggunakan metode TOPSIS (Technique For Others Reference by Similarity to deal Solution) yang menghasilkan nilai rangking karyawan dalam seleksi pemberian gaji bonus pada restoran KL Express (Brata and Whidyanto 2017). Penelitian berikutnya menyatakan bahwa dengan adanya sistem pendukung keputusan ini dapat mengatasi masalah pemberian bonus gaji karyawan yang dianggap kurang adil dan kurang 
efektif dengan metode AHP (Analitycal Hierarchy Process) (Manurung 2017). Sedangkan pada penelitian ini menggunakan metode MFEP dimana pada metode ini menggunakan kriteria yang mana masing-masing kriteria diberi nilai bobot dan jumlah nilai bobot dari masingmasing kriteria tersebut harus sama dengan satu (Noviandha, Astuti, and Kridalaksana 2019).

Berdasarkan penelitian sebelumnya, metode yang dipakai dalam pendukung keputusan pemberian reward/bonus pada penyiar Radio Kiara 96,7 Fm adalah metode Multi Factor Evaluation Process karena, metode ini dapat menyeleksi penyiar dari berbagai alternatif lainnya yang berhak mendapatkan bonus dari perusahaan tersebut. Dengan adanya penelitian ini diharapkan mampu mengatasi permasalahan pada pemberian reward/bonus pada penyiar radio Kiara 96,7 FM Padang, Sumatera Barat.

\section{METODE PENELITIAN}

Metode penelitian yang digunakan dalam sistem pendukung keputusan pemberian reward pada penyiar radio ini adalah metode MFEP (Multifactor evaluation process). Metode ini merupakan metode kuantitatif yang menggunakan weighting system. Dalam pengambil keputusan secara subyektif dan intuitif menimbang berbagai faktor atau kriteria yang mempunyai pengaruh penting terhadap alternative pilihannya. Atau model pengambilan keputusan yang menggunakan pendekatan kolektif dari proses pengambilan keputusannya. Untuk keputusan yang berpengaruh secara strategis. Dalam MEFP pertama-tama seluruh kriteria yang menjadi faktor penting dalam melakukan pertimbangan diberikan pembobotan (weighting) yang sesuai. Langkah yang sama juga dilakukan terhadap alternative-alternatif yang akan dipilih, yang kemudian dapat dievaluasi berkaitan dengan factor-faktor pertimbangan tersebut. Metode MFEP menentukan bahwa alternative dengan nilai tertinggi adalah solusi terbaik berdasarkan kriteria yang telah dipilih (Vadreas, Nirad, and Aldo 2020).

Adapun tahapan-tahapan dalam proses penghitungan menggunakan metode Multifactor Evaluation Process (MFEP) (Vadreas, Rifa, and Ardiansyah 2018), sebagai berikut :

a. Menentukan faktor / kriteria dan bobot faktor dimana total pembobotan harus sama dengan 1 atau $100(\Sigma$ pembobotan $=1$ ), yaitu factor weight.

b. Mengisikan nilai untuk setiap faktor yang mempengaruhi dalam pengambilan keputusan dari data-data yang akan diproses, nilai yang dimasukkan dalam proses pengambilan keputusan merupakan nilai objektif, yaitu sudah pasti factor evaluation yang nilainya antara $0-1$ ( 0-100).

Proses perhitungan weight evaluation yang merupakan proses perhitungan bobot antara factor weight dan factor evaluation dengan penjumlahan seluruh hasil weight evaluations untuk memperoleh hasil evaluasi. Nilai weight evaluation (yij) dari suatu alternative ke - I pada kriyeria/faktor ke-j merupakan hasil perkalian dari factor weight (wj) yang dinyatakan dalam persamaan sebagai berikut :

$$
V_{i}=\sum_{j=i}^{n} w_{j} * r_{i j}=\sum_{j=1}^{n} y_{i j}
$$

Keterangan :

- Yij : Weight Evaluation Alternatif ke - I pada kriteria ke - j

- $\mathrm{Wj}$ : Weight Factor kriteria ke - j

- rij : Factor Evaluasi alternative ke I pada kriteria $\mathrm{ke}-\mathrm{j}$

- Vi :Nilai total evaluasi/preferensi dari alternative ke - $\mathrm{i}$

n : Jumlah kriteria

Proses perangkingan dari Nilai Total Evaluasi/ preferensi yang diperoleh, dimana nilai yang tertinggi adalah yang terbaik sesuai kriteria/ faktor yang ditentukan. 
Pada penelitian pemberian reward/ bonus pada penyiar PT. Radio Kiara Indah Berjaya yang berhak menerimanya, harus memenuhi kriteria-kriteria serta alternative yang telah ditentukan yaitu pada Tabel 1 dan Tabel 2 :

Tabel 1 Kriteria Penerima Reward/Bonus

\begin{tabular}{ccll}
\multicolumn{2}{c}{ Tabel 1 Kriteria Penerima Reward/Bonus } \\
\hline No & Kode & Keterangan & \multicolumn{1}{c}{ Keterangan } \\
\hline 1 & K1 & Absensi & JK : Jumlah Kehadiran \\
\hline 2 & K2 & Sikap Kerja & $\begin{array}{l}\text { KT : Ketelitian } \\
\text { TJ : Tanggung Jawab } \\
\text { PP : Pengendalian perasaan saat siaran }\end{array}$ \\
\hline 3 & K3 & $\begin{array}{l}\text { Kemampuan } \\
\text { Komunikasi }\end{array}$ & $\begin{array}{l}\text { PM : Penyampaian Materi } \\
\text { PK : Pemilihan Kata } \\
\text { KB : Kemampuan Berbicara }\end{array}$ \\
\hline 4 & K4 & $\begin{array}{l}\text { Pemilihan } \\
\text { Lagu }\end{array}$ & RP : Respon Pendengar \\
\hline 5 & K5 & $\begin{array}{l}\text { Pendengar / } \\
\text { Audience }\end{array}$ & RP : Respon Pendengar \\
\hline 6 & K6 & Masa Kerja & LB : Lama Bekerja \\
\hline
\end{tabular}

Dari Tabel 1 di atas dapat di jelaskan bahwa semua kriteria sangat berpengaruh terhadap penilaian penyiar. Kriteriakriteria tersebut di dapat dari hasil diskusi atau kerja sama dari pimpinan serta karyawan-karyawan yang dilibatkan dalam menentukan penyiar yang berhak menerima reward/bonus, sebagai apresiasi atas kinerja mereka untuk perusahaan selama ini serta penyemangat bagi semua penyiar supaya dapat bekerja lebih baik lagi ke depannya .

Tabel 2. Alternatif Penerima Reward/Bonus

\begin{tabular}{ccl}
\hline No & Kode & \multicolumn{1}{c}{ Keterangan } \\
\hline 1 & P1 & Malin Deman \\
\hline 2 & P2 & Pitto Mansiang \\
\hline 3 & P3 & Aziz Rusli \\
\hline 4 & P4 & Nuri Lenggogeni \\
\hline 5 & P5 & Tya Ambun Suri \\
\hline 6 & P6 & Nilam Sari \\
\hline 7 & P7 & Vanny Osega \\
\hline 8 & P8 & Nouval Palala \\
\hline 9 & P9 & Opy Yuristia \\
\hline 10 & P10 & Rosa Candrima \\
\hline 11 & P11 & Siti Maisyaroh \\
\hline 12 & P12 & Ari Fauzan \\
\hline 13 & P13 & Resty Kinanti \\
\hline 14 & P14 & Nana Kemala \\
\hline 15 & P15 & Akbar Koto \\
\hline 16 & P16 & Uci Nur'aini \\
\hline
\end{tabular}

\section{HASIL DAN PEMBAHASAN}

Proses perhitungan yang dilakukan dalam sistem pendukung keputasan dalam pemberian reward penyiar radio dengan metode MFEP ini terdiri dari beberapa tahapan yang antara lain :

a. Menentukan Factor Weight

Faktor weight bertujuan untuk menentukan faktor dan bobot faktor dimana total pembobotan harus sama dengan $1(\Sigma$ pembobotan $=1)$. Nilai dari factor weight dapat dilihat pada Tabel 3.

Tabel 3. Factor Weight

\begin{tabular}{clc} 
Kode_Kriteria & Nama_Kriteria & Bobot \\
\hline K1 & Absensi & 0,1 \\
K2 & Sikap Kerja & 0.15 \\
K3 & $\begin{array}{l}\text { Kemampuan } \\
\text { Komunikasi }\end{array}$ & 0.3 \\
\hline K4 & Pemilihan Lagu & 0.15 \\
\hline K5 & Audience/Pendengar & 0,2 \\
\hline K6 & Masa Kerja & 0,1 \\
\hline & Jumlah & $\mathbf{1}$
\end{tabular}

Data kriteria diperoleh dari hasil penilaian para penyiar sehari-hari. Sedangkan nilai factor weight diperoleh dari hasil program director dengan pimpinan Radio Kiara 96,7 Fm.

\section{b. Menentukan Factor Evaluation}

Mengisikan nilai untuk setiap faktor yang mempengaruhi dalam pengambilan keputusan dari data-data yang akan diproses, nilai yang dimasukkan dalam proses pengambilan keputusan merupakan nilai objektif, yaitu sudah pasti factor evaluation yang nilainya antara $0-10$. Nilai dari factor evaluation dapat dilihat pada Tabel 4.

Tabel 4. Nilai Factor Evaluation

\begin{tabular}{|c|c|c|c|c|}
\hline No & Kriteria & Range & Sub Kriteria & Nilai \\
\hline \multirow{4}{*}{1} & \multirow{4}{*}{ Absensi } & $>91 \%$ & Sangat rajin & 4 \\
\hline & & $90 \%-71 \%$ & Rajin & 3 \\
\hline & & $70 \%-55 \%$ & Cukup & 2 \\
\hline & & $<54 \%$ & Kurang & 1 \\
\hline \multirow{4}{*}{2} & \multirow{4}{*}{ Sikap Kerja } & $>=90$ & Sangat baik & 4 \\
\hline & & $89-76$ & Baik & 3 \\
\hline & & $75-60$ & Cukup & 2 \\
\hline & & $<=59$ & Kurang & 1 \\
\hline \multirow{4}{*}{3} & \multirow{4}{*}{$\begin{array}{l}\text { Kemampuan } \\
\text { Komunikasi }\end{array}$} & $100-86$ & Sangat Baik & 4 \\
\hline & & $85-66$ & Baik & 3 \\
\hline & & $65-51$ & Cukup & 2 \\
\hline & & $<=50$ & Kurang & 1 \\
\hline \multirow{4}{*}{4} & \multirow{4}{*}{$\begin{array}{l}\text { Pemilihan } \\
\text { Lagu }\end{array}$} & $100-76$ & Sangat bagus & 4 \\
\hline & & $75-60$ & bagus & 3 \\
\hline & & $59-45$ & Cukup & 2 \\
\hline & & $<=44$ & Kurang & 1 \\
\hline \multirow{3}{*}{5} & \multirow{3}{*}{$\begin{array}{c}\text { Pendengar / } \\
\text { Audience }\end{array}$} & $100-70$ & Sangat Suka & 4 \\
\hline & & $69-50$ & Suka & 3 \\
\hline & & $<=49$ & Cukup & 2 \\
\hline \multirow{2}{*}{6} & \multirow{2}{*}{ Masa Kerja } & $<=2$ Tahun & Pemula & 1 \\
\hline & & $3-5$ Tahun & Mampu & 2 \\
\hline
\end{tabular}




\begin{tabular}{lll}
$6-10$ Tahun & Cakap & 3 \\
\hline $11-15$ Tahun & Ahli & 4 \\
\hline$>=16$ Tahun & Master & 5 \\
\hline
\end{tabular}

Sub kriteria diperoleh dari hasil keputusan dari radio Kiara 96,7 Fm dan yang mana telah sesuai dengan syaratsyarat yang harus dipenuhi oleh setiap penyiar dalam Siaran.

\section{c. Perhitungan Metode MFEP}

Proses perhitungan dengan metode MFEP, dapat ditunjukkan pada Tabel 5.

Tabel 5. Proses Perhitungan Metode MFEP

\begin{tabular}{clcccccc}
\hline Kode & Keterangan & C1 & C2 & C3 & C4 & C5 & C6 \\
\hline P1 & Malin Deman & $96 \%$ & 83,7 & 100 & 100 & 48 & 19 Thn \\
\hline P2 & Aziz Rusli & $30 \%$ & 84,7 & 64 & 40 & 12 & 12 Thn \\
\hline P3 & $\begin{array}{l}\text { Nuri } \\
\text { lengogeni }\end{array}$ & $90 \%$ & 85 & 67 & 42 & 17 & 6 Thn \\
\hline P4 & $\begin{array}{l}\text { Tya Ambun } \\
\text { Suri }\end{array}$ & $90 \%$ & 82,7 & 61 & 35 & 15 & 8 Thn \\
\hline P5 & Nilam Sari & $99 \%$ & 91,7 & 70 & 55 & 46 & 6 Thn \\
\hline P6 & Vanny Osega & $\begin{array}{c}100 \\
\%\end{array}$ & 91 & 73 & 60 & 10 & 9 Thn \\
\hline P7 & Nouval Palala & $10 \%$ & 83,3 & 100 & 100 & 12 & 10 Thn \\
\hline P8 & Opy Yuristia & $98 \%$ & 91 & 60 & 32 & 12 & 2 Thn \\
\hline P9 & $\begin{array}{l}\text { Rosa } \\
\text { Candrima }\end{array}$ & $25 \%$ & 83,3 & 73 & 61 & 9 & 5 Thn \\
\hline P10 & Ari Fauzan & $\begin{array}{c}100 \\
\%\end{array}$ & 91,3 & 64 & 43 & 20 & 2 Thn \\
\hline P11 & Siti Maisaroh & $85 \%$ & 90 & 64 & 45 & 13 & 2 Thn \\
\hline P12 & Nana Kemala & $95 \%$ & 88,3 & 78 & 72 & 13 & 3 Thn \\
\hline P13 & Resty Kinanti & $95 \%$ & 90,3 & 65 & 43 & 17 & 3 Thn \\
\hline P14 & Akbar Koto & $99 \%$ & 90,7 & 69 & 50 & 14 & 2 Thn \\
\hline P15 & Uci Nuraini & $98 \%$ & 90,3 & 70 & 53 & 15 & 1 Thn \\
\hline P16 & $\begin{array}{l}\text { Pitto } \\
\text { Mansiang }\end{array}$ & $98 \%$ & 91 & 78 & 67 & 19 & 1 Thn \\
\hline
\end{tabular}

Keterangan :

1) $\mathrm{C} 1=$ Absensi, $\mathrm{C} 2=$ Sikap Kerja, $\mathrm{C} 3$ $=$ Kemampuan Komunikasi, $\mathrm{C} 4=$ Pemilihan Lagu, C5 = Audience/ Pendengar, C6 = Masa Kerja

2) Absensi diperoleh dari jumlah kehadiran penyiar saat siaran.

3) Sikap kerja di peroleh dari penilaian staff dan pimpinan.

4) Kemampuan komunikasi diperoleh dari pengabungan pengabungan penilaian pimpinan dan pendengar.

5) Audience/pendengar nilainya di peroleh dari penilaian 100 orang pendengar yang dipilih secara acak.

6) Pemilihan lagu nilainya di peroleh dari suara 100 orang pendengar yang dipilih secara acak.

d. Nilai Range
Nilai acuan dari setiap kriteria dari alternatif di dapat dari acuan range, ditunjukkan pada Tabel 6.

Tabel 6. Nilai Range

\begin{tabular}{clcccccc}
\hline Kode & Keterangan & C1 & C2 & C3 & C4 & C5 & C6 \\
\hline P1 & $\begin{array}{l}\text { Malin } \\
\text { Deman }\end{array}$ & 4 & 3 & 4 & 4 & 2 & 5 \\
\hline P2 & Aziz Rusli & 1 & 3 & 2 & 1 & 2 & 4 \\
\hline P3 & $\begin{array}{l}\text { Nuri } \\
\text { Lenggogeni }\end{array}$ & 3 & 3 & 3 & 1 & 2 & 3 \\
\hline P4 & $\begin{array}{l}\text { Tya Ambun } \\
\text { Suri }\end{array}$ & 3 & 3 & 2 & 1 & 2 & 3 \\
\hline P5 & Nilam Sari & 4 & 4 & 3 & 2 & 2 & 3 \\
\hline P6 & Vanny Osega & 4 & 4 & 3 & 3 & 2 & 3 \\
\hline P7 & $\begin{array}{l}\text { Nouval } \\
\text { Palala }\end{array}$ & 1 & 3 & 4 & 4 & 2 & 3 \\
\hline P8 & Opy Yuristia & 4 & 4 & 2 & 1 & 2 & 1 \\
\hline P9 & $\begin{array}{l}\text { Rosa } \\
\text { Candrima }\end{array}$ & 1 & 3 & 3 & 3 & 2 & 2 \\
\hline P10 & Ari Fauzan & 4 & 4 & 2 & 1 & 2 & 1 \\
\hline P11 & $\begin{array}{l}\text { Siti } \\
\text { Maisyaroh }\end{array}$ & 3 & 4 & 2 & 2 & 2 & 1 \\
\hline P12 & Nana Kemala & 4 & 3 & 3 & 3 & 2 & 2 \\
\hline P13 & $\begin{array}{l}\text { Resty } \\
\text { Kinanti }\end{array}$ & 4 & 4 & 2 & 1 & 2 & 2 \\
\hline P14 & Akbar Koto & 4 & 4 & 3 & 2 & 2 & 1 \\
\hline P15 & Uci Nuraini & 4 & 4 & 3 & 2 & 2 & 1 \\
\hline P16 & $\begin{array}{l}\text { Pitto } \\
\text { Mansiang }\end{array}$ & 4 & 4 & 3 & 3 & 2 & 1 \\
\hline & & & & & & \\
\hline
\end{tabular}

e. Proses Penghitungan Weight

Evaluation

1. Hasil perhitungan bobot (weight evaluation) untuk penyiar Malin Deman, ditunjukkan pada Tabel 7.

Tabel 7. Perhitungan Weight Evaluation Malin Deman

\begin{tabular}{clccc}
\hline No & Nama Kriteria & $\begin{array}{c}\text { Nilai } \\
\text { Kriteria }\end{array}$ & $\begin{array}{c}\text { Faktor } \\
\text { Weight }\end{array}$ & $\begin{array}{c}\text { Weight } \\
\text { Evaluation }\end{array}$ \\
\hline 1 & Absensi & 4 & 0,1 & 0,4 \\
\hline 2 & Sikap Kerja & 3 & 0.15 & 0,45 \\
\hline 3 & $\begin{array}{l}\text { Kemampuan } \\
\text { Komunikasi }\end{array}$ & 4 & 0.3 & 1,2 \\
\hline 4 & Pemilihan Lagu & 4 & 0.15 & 0,6 \\
\hline 5 & $\begin{array}{l}\text { Audience/ } \\
\text { Pendengar }\end{array}$ & 2 & 0,2 & 0,4 \\
\hline 6 & Masa Kerja & 5 & 0,1 & 0,5 \\
\hline \multicolumn{4}{c}{ Total Hasil Evaluasi } \\
\hline
\end{tabular}

2. Hasil perhitungan bobot (weight evaluation) untuk penyiar Pitto Mansiang, ditunjukkan pada Tabel 8.

Tabel 8. Perhitungan Weight Evaluation Pitto Mansiang

\begin{tabular}{clccc}
\hline No & Nama Kriteria & $\begin{array}{c}\text { Nilai } \\
\text { Kriteria }\end{array}$ & $\begin{array}{c}\text { Faktor } \\
\text { Weight }\end{array}$ & $\begin{array}{c}\text { Weight } \\
\text { Evaluation }\end{array}$ \\
\hline 1 & Absensi & 4 & 0,1 & 0,4 \\
\hline 2 & Sikap Kerja & 4 & 0.15 & 0,6 \\
\hline
\end{tabular}




\begin{tabular}{clccc}
3 & $\begin{array}{l}\text { Kemampuan } \\
\text { Komunikasi }\end{array}$ & 3 & 0.3 & 0,9 \\
\hline 4 & Pemilihan Lagu & 3 & 0.15 & 0,45 \\
\hline 5 & $\begin{array}{l}\text { Audience/ } \\
\text { Pendengar }\end{array}$ & 2 & 0,2 & 0,4 \\
\hline 6 & Masa Kerja & 1 & 0,1 & 0,1 \\
\hline \multicolumn{5}{c}{ Total Hasil Evaluasi } \\
\hline
\end{tabular}

6. Hasil perhitungan bobot (weight evaluation) untuk penyiar Nilam sari, ditunjukkan pada Tabel 12.

3. Hasil perhitungan bobot (weight evaluation) untuk penyiar Aziz Rusli, ditunjukkan pada Tabel 9.

Tabel 9. Perhitungan Weight Evaluation Aziz

\begin{tabular}{clccc} 
Rusli & & \\
\hline No & Nama Kriteria & $\begin{array}{c}\text { Nilai } \\
\text { Kriteria }\end{array}$ & $\begin{array}{c}\text { Faktor } \\
\text { Weight }\end{array}$ & $\begin{array}{c}\text { Weight } \\
\text { Evaluation }\end{array}$ \\
\hline 1 & Absensi & 1 & 0,1 & 0,1 \\
\hline 2 & Sikap Kerja & 3 & 0.15 & 0,45 \\
\hline 3 & $\begin{array}{l}\text { Kemampuan } \\
\text { Komunikasi }\end{array}$ & 2 & 0.3 & 0,6 \\
\hline 4 & Pemilihan Lagu & 1 & 0.15 & 0,15 \\
\hline 5 & $\begin{array}{l}\text { Audience/ } \\
\text { Pendengar }\end{array}$ & 2 & 0,2 & 0,4 \\
\hline 6 & Masa Kerja & 4 & 0,1 & 0,4 \\
\hline \multicolumn{2}{c}{ Total Hasil Evaluasi } & & $\mathbf{2 , 1 0}$
\end{tabular}

4. Hasil perhitungan bobot (weight evaluation) untuk penyiar Nuri Lenggogeni, ditunjukkan pada Tabel 10.

Tabel 10. Perhitungan Weight Evaluation Nuri Lenggogeni

\begin{tabular}{clccc}
\hline No & Nama Kriteria & $\begin{array}{c}\text { Nilai } \\
\text { Kriteria }\end{array}$ & $\begin{array}{c}\text { Faktor } \\
\text { Weight }\end{array}$ & $\begin{array}{c}\text { Weight } \\
\text { Evaluation }\end{array}$ \\
\hline 1 & Absensi & 3 & 0,1 & 0,3 \\
\hline 2 & Sikap Kerja & 3 & 0.15 & 0,45 \\
\hline 3 & $\begin{array}{l}\text { Kemampuan } \\
\text { Komunikasi }\end{array}$ & 3 & 0.3 & 0,9 \\
\hline 4 & Pemilihan Lagu & 1 & 0.15 & 0,15 \\
\hline 5 & $\begin{array}{l}\text { Audience/ } \\
\text { Pendengar }\end{array}$ & 2 & 0,2 & 0,4 \\
\hline 6 & Masa Kerja & 3 & 0,1 & 0,3 \\
\hline \multicolumn{5}{c}{ Total Hasil Evaluasi } \\
\hline
\end{tabular}

5. Hasil perhitungan bobot (weight evaluation) untuk penyiar Tya Ambun Suri, ditunjukkan pada Tabel 11.

Tabel 11. Perhitungan Weight Evaluation Tya Ambun Suri

\begin{tabular}{clccc}
\hline No & Nama Kriteria & $\begin{array}{c}\text { Nilai } \\
\text { Kriteria }\end{array}$ & $\begin{array}{c}\text { Faktor } \\
\text { Weight }\end{array}$ & $\begin{array}{c}\text { Weight } \\
\text { Evaluation }\end{array}$ \\
\hline 1 & Absensi & 3 & 0,1 & 0,3 \\
\hline 2 & Sikap Kerja & 3 & 0.15 & 0,45 \\
\hline 3 & $\begin{array}{l}\text { Kemampuan } \\
\text { Komunikasi }\end{array}$ & 2 & 0.3 & 0,6 \\
\hline 4 & Pemilihan Lagu & 1 & 0.15 & 0,15 \\
\hline 5 & $\begin{array}{l}\text { Audience/ } \\
\text { Pendengar }\end{array}$ & 2 & 0,2 & 0,4 \\
\hline 6 & Masa Kerja & 3 & 0,1 & 0,3 \\
\hline \multicolumn{5}{c}{ Total Hasil Evaluasi } \\
\hline
\end{tabular}

Tabel 12. Perhitungan Weight Evaluation Nilam sari

\begin{tabular}{clccc}
\hline Sari & Naktor & $\begin{array}{c}\text { Weight } \\
\text { Evaluation }\end{array}$ \\
\hline 1 & Absensi & 4 & 0,1 & 0,4 \\
\hline 2 & Sikap Kerja & 4 & 0.15 & 0,6 \\
\hline 3 & $\begin{array}{l}\text { Kemampuan } \\
\text { Komunikasi }\end{array}$ & 3 & 0.3 & 0,9 \\
\hline 4 & Pemilihan Lagu & 2 & 0.15 & 0,15 \\
\hline 5 & $\begin{array}{l}\text { Audience/ } \\
\text { Pendengar }\end{array}$ & 2 & 0,2 & 0,4 \\
\hline 6 & Masa Kerja & 3 & 0,1 & 0,3 \\
\hline \multicolumn{5}{c}{ Total Hasil Evaluasi } \\
\hline \multicolumn{4}{c}{}
\end{tabular}

7. Hasil perhitungan bobot (weight evaluation) untuk penyiar vanny Osega, ditunjukkan pada Tabel 13.

Tabel 13. Perhitungan Weight Evaluation vanny Osega

\begin{tabular}{clccc}
\hline No & Nama Kriteria & $\begin{array}{c}\text { Nilai } \\
\text { Kriteria }\end{array}$ & $\begin{array}{c}\text { Faktor } \\
\text { Weight }\end{array}$ & $\begin{array}{c}\text { Weight } \\
\text { Evaluation }\end{array}$ \\
\hline 1 & Absensi & 4 & 0,1 & 0,4 \\
\hline 2 & Sikap Kerja & 4 & 0.15 & 0,6 \\
\hline 3 & $\begin{array}{l}\text { Kemampuan } \\
\text { Komunikasi }\end{array}$ & 3 & 0.3 & 0,9 \\
\hline 4 & Pemilihan Lagu & 3 & 0.15 & 0,45 \\
\hline 5 & $\begin{array}{l}\text { Audience/ } \\
\text { Pendengar }\end{array}$ & 2 & 0,2 & 0,4 \\
\hline 6 & Masa Kerja & 3 & 0,1 & 0,3 \\
\hline \multicolumn{5}{c}{ Total Hasil Evaluasi } \\
\hline
\end{tabular}

8. Hasil perhitungan bobot (weight evaluation) untuk penyiar Nouval Palala, ditunjukkan pada Tabel 14.

Tabel 14. Perhitungan Weight Evaluation Nouval Palala

\begin{tabular}{clccc}
\hline No & Nama Kriteria & $\begin{array}{c}\text { Nilai } \\
\text { Kriteria }\end{array}$ & $\begin{array}{c}\text { Faktor } \\
\text { Weight }\end{array}$ & $\begin{array}{c}\text { Weight } \\
\text { Evaluation }\end{array}$ \\
\hline 1 & Absensi & 1 & 0,1 & 0,1 \\
\hline 2 & Sikap Kerja & 3 & 0.15 & 0,45 \\
\hline 3 & $\begin{array}{l}\text { Kemampuan } \\
\text { Komunikasi }\end{array}$ & 4 & 0.3 & 1,2 \\
\hline 4 & Pemilihan Lagu & 4 & 0.15 & 0,6 \\
\hline 5 & $\begin{array}{l}\text { Audience/ } \\
\text { Pendengar }\end{array}$ & 2 & 0,2 & 0,4 \\
\hline 6 & Masa Kerja & 3 & 0,1 & 0,3 \\
\hline \multicolumn{5}{c}{ Total Hasil Evaluasi } \\
\hline
\end{tabular}

9. Hasil perhitungan bobot (weight evaluation) untuk penyiar Opi Yuristia, ditunjukkan pada Tabel 15.

Tabel 15. Perhitungan Weight Evaluation Opi Yuristia

\begin{tabular}{lllll}
\hline No & Nama Kriteria & Nilai & Faktor & Weight \\
\hline
\end{tabular}


DOI : https://doi.org/10.47233/jteksis.v3i2.242

\begin{tabular}{clccc}
\hline & & Kriteria & Weight & Evaluation \\
\hline 1 & Absensi & 4 & 0,1 & 0,4 \\
\hline 2 & Sikap Kerja & 4 & 0.15 & 0,6 \\
\hline 3 & $\begin{array}{l}\text { Kemampuan } \\
\text { Komunikasi }\end{array}$ & 2 & 0.3 & 0,6 \\
\hline 4 & Pemilihan Lagu & 1 & 0.15 & 0,15 \\
\hline 5 & $\begin{array}{l}\text { Audience/ } \\
\text { Pendengar }\end{array}$ & 2 & 0,2 & 0,4 \\
\hline 6 & Masa Kerja & 1 & 0,1 & 0,1 \\
\hline \multicolumn{5}{c}{ Total Hasil Evaluasi } \\
\hline
\end{tabular}

\begin{tabular}{clccc}
5 & $\begin{array}{l}\text { Audience/ } \\
\text { Pendengar }\end{array}$ & 2 & 0,2 & 0,4 \\
\hline 6 & Masa Kerja & 1 & 0,1 & 0,1 \\
\hline \multicolumn{4}{c}{ Total Hasil Evaluasi } \\
\hline \multicolumn{2}{c}{ Has }
\end{tabular}

13. Hasil perhitungan bobot (weight evaluation) untuk penyiar Resty Kinanti, ditunjukkan pada Tabel 19.

10. Hasil perhitungan bobot (weight evaluation) untuk penyiar Siti Maisyaroh, ditunjukkan pada Tabel 16.

Tabel 16. Perhitungan Weight Evaluation Siti Maisyaroh

\begin{tabular}{clccc}
\hline \multicolumn{5}{c}{ Maisyaroh } \\
No & Nama Kriteria & $\begin{array}{c}\text { Nilai } \\
\text { Kriteria }\end{array}$ & $\begin{array}{c}\text { Faktor } \\
\text { Weight }\end{array}$ & $\begin{array}{c}\text { Weight } \\
\text { Evaluation }\end{array}$ \\
\hline 1 & Absensi & 3 & 0,1 & 0,3 \\
\hline 2 & Sikap Kerja & 4 & 0.15 & 0,6 \\
\hline 3 & $\begin{array}{l}\text { Kemampuan } \\
\text { Komunikasi }\end{array}$ & 2 & 0.3 & 0,6 \\
\hline 4 & Pemilihan Lagu & 2 & 0.15 & 0,3 \\
\hline 5 & $\begin{array}{l}\text { Audience/ } \\
\text { Pendengar }\end{array}$ & 2 & 0,2 & 0,4 \\
\hline 6 & Masa Kerja & 1 & 0,1 & 0,1 \\
\hline \multicolumn{2}{r}{ Total Hasil Evaluasi } \\
\hline
\end{tabular}

Tabel 19. Perhitungan Weight Evaluation Resty Kinanti

\begin{tabular}{clccc} 
No & Nama Kriteria & $\begin{array}{c}\text { Nilai } \\
\text { Kriteria }\end{array}$ & $\begin{array}{c}\text { Faktor } \\
\text { Weight }\end{array}$ & $\begin{array}{c}\text { Weight } \\
\text { Evaluation }\end{array}$ \\
\hline 1 & Absensi & 4 & 0,1 & 0,4 \\
\hline 2 & Sikap Kerja & 4 & 0.15 & 0,6 \\
\hline 3 & $\begin{array}{l}\text { Kemampuan } \\
\text { Komunikasi }\end{array}$ & 2 & 0.3 & 0,6 \\
\hline 4 & Pemilihan Lagu & 1 & 0.15 & 0,15 \\
\hline 5 & $\begin{array}{l}\text { Audience/ } \\
\text { Pendengar }\end{array}$ & 2 & 0,2 & 0,4 \\
\hline 6 & Masa Kerja & 2 & 0,1 & 0,2 \\
\hline \multicolumn{4}{r}{ Total Hasil Evaluasi } & \\
\hline
\end{tabular}

14. Hasil perhitungan bobot (weight evaluation) untuk penyiar Nana Kemala, ditunjukkan pada Tabel 20.

Tabel 20. Perhitungan Weight Evaluation Nana Kemala

11. Hasil perhitungan bobot (weight evaluation) untuk penyiar Rosa Candrima, ditunjukkan pada Tabel 17.

Tabel 17. Perhitungan Weight Evaluation Rosa Candrima

\begin{tabular}{clccc}
\hline No & Nama Kriteria & $\begin{array}{c}\text { Nilai } \\
\text { Kriteria }\end{array}$ & $\begin{array}{c}\text { Faktor } \\
\text { Weight }\end{array}$ & $\begin{array}{c}\text { Weight } \\
\text { Evaluation }\end{array}$ \\
\hline 1 & Absensi & 1 & 0,1 & 0,1 \\
\hline 2 & Sikap Kerja & 3 & 0.15 & 0,45 \\
\hline 3 & $\begin{array}{l}\text { Kemampuan } \\
\text { Komunikasi }\end{array}$ & 3 & 0.3 & 0,9 \\
\hline 4 & Pemilihan Lagu & 3 & 0.15 & 0,45 \\
\hline 5 & $\begin{array}{l}\text { Audience/ } \\
\text { Pendengar }\end{array}$ & 2 & 0,2 & 0,4 \\
\hline 6 & Masa Kerja & 2 & 0,1 & 0,2 \\
\hline \multicolumn{2}{r}{ Total Hasil Evaluasi } \\
\hline
\end{tabular}

12. Hasil perhitungan bobot (weight evaluation) untuk penyiar Ari Fauzan, ditunjukkan pada Tabel 18.

Tabel 18. Perhitungan Weight Evaluation Ari Fauzan

\begin{tabular}{clccc}
\hline No & Nama Kriteria & $\begin{array}{c}\text { Nilai } \\
\text { Kriteria }\end{array}$ & $\begin{array}{c}\text { Faktor } \\
\text { Weight }\end{array}$ & $\begin{array}{c}\text { Weight } \\
\text { Evaluation }\end{array}$ \\
\hline 1 & Absensi & 4 & 0,1 & 0,4 \\
\hline 2 & Sikap Kerja & 4 & 0.15 & 0,6 \\
\hline 3 & $\begin{array}{l}\text { Kemampuan } \\
\text { Komunikasi }\end{array}$ & 2 & 0.3 & 0,6 \\
\hline 4 & Pemilihan Lagu & 1 & 0.15 & 0,15 \\
\hline
\end{tabular}

\begin{tabular}{clccc}
\hline No & Nama Kriteria & $\begin{array}{c}\text { Nilai } \\
\text { Kriteria }\end{array}$ & $\begin{array}{c}\text { Faktor } \\
\text { Weight }\end{array}$ & $\begin{array}{c}\text { Weight } \\
\text { Evaluation }\end{array}$ \\
\hline 1 & Absensi & 4 & 0,1 & 0,4 \\
\hline 2 & Sikap Kerja & 3 & 0.15 & 0,45 \\
\hline 3 & $\begin{array}{l}\text { Kemampuan } \\
\text { Komunikasi }\end{array}$ & 3 & 0.3 & 0,9 \\
\hline 4 & Pemilihan Lagu & 3 & 0.15 & 0,45 \\
\hline 5 & $\begin{array}{l}\text { Audience/ } \\
\text { Pendengar }\end{array}$ & 2 & 0,2 & 0,4 \\
\hline 6 & Masa Kerja & 2 & 0,1 & 0,2 \\
\hline \multicolumn{5}{c}{ Total Hasil Evaluasi } \\
\hline
\end{tabular}

15. Hasil perhitungan bobot (weight evaluation) untuk penyiar Akbar Koto, ditunjukkan pada Tabel 21.

Tabel 21. Perhitungan Weight Evaluation Akbar Koto

\begin{tabular}{clccc}
\hline No & Nama Kriteria & $\begin{array}{c}\text { Nilai } \\
\text { Kriteria }\end{array}$ & $\begin{array}{c}\text { Faktor } \\
\text { Weight }\end{array}$ & $\begin{array}{c}\text { Weight } \\
\text { Evaluation }\end{array}$ \\
\hline 1 & Absensi & 4 & 0,1 & 0,4 \\
\hline 2 & Sikap Kerja & 4 & 0.15 & 0,6 \\
\hline 3 & $\begin{array}{l}\text { Kemampuan } \\
\text { Komunikasi }\end{array}$ & 3 & 0.3 & 0,9 \\
\hline 4 & Pemilihan Lagu & 2 & 0.15 & 0,3 \\
\hline 5 & $\begin{array}{l}\text { Audience/ } \\
\text { Pendengar }\end{array}$ & 2 & 0,2 & 0,4 \\
\hline 6 & Masa Kerja & 1 & 0,1 & 0,1 \\
\hline \multicolumn{4}{c}{ Total Hasil Evaluasi } \\
\hline
\end{tabular}

16. Hasil perhitungan bobot (weight evaluation) untuk penyiar Uci Nuraini, ditunjukkan pada Tabel 22. 
Tabel 22. Perhitungan Weight Evaluation Uci Nuraini

\begin{tabular}{clccc}
\hline No & Nama Kriteria & $\begin{array}{c}\text { Nilai } \\
\text { Kriteria }\end{array}$ & $\begin{array}{c}\text { Faktor } \\
\text { Weight }\end{array}$ & $\begin{array}{c}\text { Weight } \\
\text { Evaluation }\end{array}$ \\
\hline 1 & Absensi & 4 & 0,1 & 0,4 \\
\hline 2 & Sikap Kerja & 4 & 0.15 & 0,6 \\
\hline 3 & $\begin{array}{l}\text { Kemampuan } \\
\text { Komunikasi }\end{array}$ & 3 & 0.3 & 0,9 \\
\hline 4 & Pemilihan Lagu & 2 & 0.15 & 0,3 \\
\hline 5 & $\begin{array}{l}\text { Audience/ } \\
\text { Pendengar }\end{array}$ & 2 & 0,2 & 0,4 \\
\hline 6 & Masa Kerja & 1 & 0,1 & 0,1 \\
\hline \multicolumn{5}{c}{ Total Hasil Evaluasi } \\
\hline
\end{tabular}

f. Hasil Penilaian Preferensi

Dari perhitungan yang telah dilakukan didapatkan hasil penilaian preferensi yang dapat menentukan siapakah penyiar yang berhak menerima reward/bonus, pada Tabel 23.

Tabel 23. Hasil Penilaian Preferensi

\begin{tabular}{|c|c|c|c|c|}
\hline No & Nama & $\begin{array}{c}\text { Total Hasil } \\
\text { Evaluasi }\end{array}$ & $\begin{array}{c}\text { Jumlah } \\
\text { Kriteria }\end{array}$ & $\begin{array}{c}\text { Nilai } \\
\text { Preferensi }\end{array}$ \\
\hline 1 & $\begin{array}{l}\text { Malin } \\
\text { Deman }\end{array}$ & 3,55 & 6 & 0,591 \\
\hline 2 & $\begin{array}{l}\text { Pitto } \\
\text { Mansiang }\end{array}$ & 2,85 & 6 & 0,475 \\
\hline 3 & Aziz Rusli & 2,10 & 6 & 0,350 \\
\hline 4 & $\begin{array}{l}\text { Nuri } \\
\text { Lenggoge } \\
\text { ni }\end{array}$ & 2,50 & 6 & 0,417 \\
\hline 5 & $\begin{array}{l}\text { Tya } \\
\text { Ambun } \\
\text { Suri }\end{array}$ & 2,20 & 6 & 0,367 \\
\hline 6 & Nilam Sari & 2,75 & 6 & 0,458 \\
\hline 7 & $\begin{array}{l}\text { Vanny } \\
\text { Osega } \\
\end{array}$ & 3,05 & 6 & 0,508 \\
\hline 8 & $\begin{array}{l}\text { Nouval } \\
\text { Palala }\end{array}$ & 3,05 & 6 & 0,508 \\
\hline 9 & $\begin{array}{l}\text { Opi } \\
\text { Yuristya }\end{array}$ & 2,25 & 6 & 0,375 \\
\hline 10 & $\begin{array}{l}\text { Siti } \\
\text { Maisyaroh }\end{array}$ & 2,30 & 6 & 0,383 \\
\hline 11 & $\begin{array}{l}\text { Rosa } \\
\text { candrima }\end{array}$ & 2,50 & 6 & 0,417 \\
\hline 12 & $\begin{array}{l}\text { Ari } \\
\text { Fauzan }\end{array}$ & 2,25 & 6 & 0,375 \\
\hline 13 & $\begin{array}{l}\text { Resty } \\
\text { Kinanti }\end{array}$ & 2,35 & 6 & 0,392 \\
\hline 14 & $\begin{array}{l}\text { Nana } \\
\text { Kemala }\end{array}$ & 2,80 & 6 & 0,467 \\
\hline 15 & $\begin{array}{l}\text { Akbar } \\
\text { Koto } \\
\end{array}$ & 2,70 & 6 & 0,450 \\
\hline 16 & $\begin{array}{l}\text { Uci } \\
\text { Nur'aini }\end{array}$ & 2,70 & 6 & 0,450 \\
\hline
\end{tabular}

Nilai Preferensi penyiar Radio Kiara 96,7 Fm didapatkan dari Pembagian antara Total hasil evaluasi dibagi dengan jumlah seluruh kriteria yang menjadi penentu utama dalam penilaian penyiar yang berhak menerima reward/bonus.

\section{g. Perangkingan}

Reward/ bonus hanya diberikan pada penyiar yang memperoleh nilai tertinggi. Oleh sebab itu tahap selanjutnya setelah melalui beberapa proses sebelumnya adalah menentukan perangkingan. Proses perangkingan untuk memastikan siapa penyiar yang mendapatkan penilaian tertinggi hingga terendah. Hasil perangkingan dapat dilihat pada Tabel 24.

Tabel 24. Hasil Perangkingan

\begin{tabular}{clcc}
\hline No & \multicolumn{1}{c}{ Nama } & $\begin{array}{c}\text { Hasil } \\
\text { Evaluasi }\end{array}$ & Rangking \\
\hline 1 & Malin Deman & 0,591 & 1 \\
\hline 2 & Vanny Osega & 0,508 & 2 \\
\hline 3 & Nouval Palala & 0,508 & 3 \\
\hline 4 & Nilam Sari & 0,458 & 4 \\
\hline 5 & Pitto Mansiang & 0,475 & 5 \\
\hline 6 & Nana Kemala & 0,467 & 6 \\
\hline 7 & Akbar Koto & 0,450 & 7 \\
\hline 8 & Uci Nur'aini & 0,450 & 8 \\
\hline 9 & Rosa candrima & 0,417 & 9 \\
\hline 10 & Nuri Lenggogeni & 0,417 & 10 \\
\hline 11 & Resty Kinanti & 0,392 & 11 \\
\hline 12 & Siti Maisyaroh & 0,383 & 12 \\
\hline 13 & Ari Fauzan & 0,375 & 13 \\
\hline 14 & Opi Yuristya & 0,375 & 14 \\
\hline 15 & Tya Ambun Suri & 0,367 & 15 \\
\hline 16 & Aziz Rusli & 0,350 & 16 \\
\hline
\end{tabular}

Dari Hasil Perengkingan diatas maka dapat dilihat penyiar yang berhak menerima reward/bonus adalah penyiar dengan nilai tertinggi yaitu Malin Deman.

\section{h. Implementasi Metode MFEP Pada}

Pemrograman

hasil pengujian metode MFEP sebelumnya akan diimplementasikan dalam bentuk tampilan dari program aplikasi sistem yang terdiri dari beberapa form.

\section{Form Login}

Form Login merupakan tampilan pertama dari sistem pendukung keputusan Penyiar PT Radio Kiara Indah Berjaya Padang dengan Metode Multifactor Evaluation Process (MFEP). Berikut ini dapat dilihat tampilan menu login yang terdiri dari form login admin untuk masuk ke beranda yang, pada Gambar 1. 

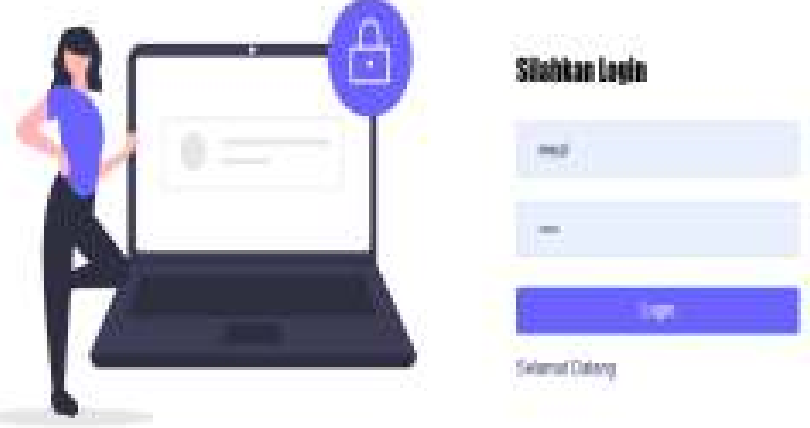

Gambar 1. Form Login Admin

\section{Form Input Data Admin}

Admin dapat mengelola semua data admin untuk login ke sistem. Untuk lebih jelas pengisian form input data admin, pada Gambar 2.

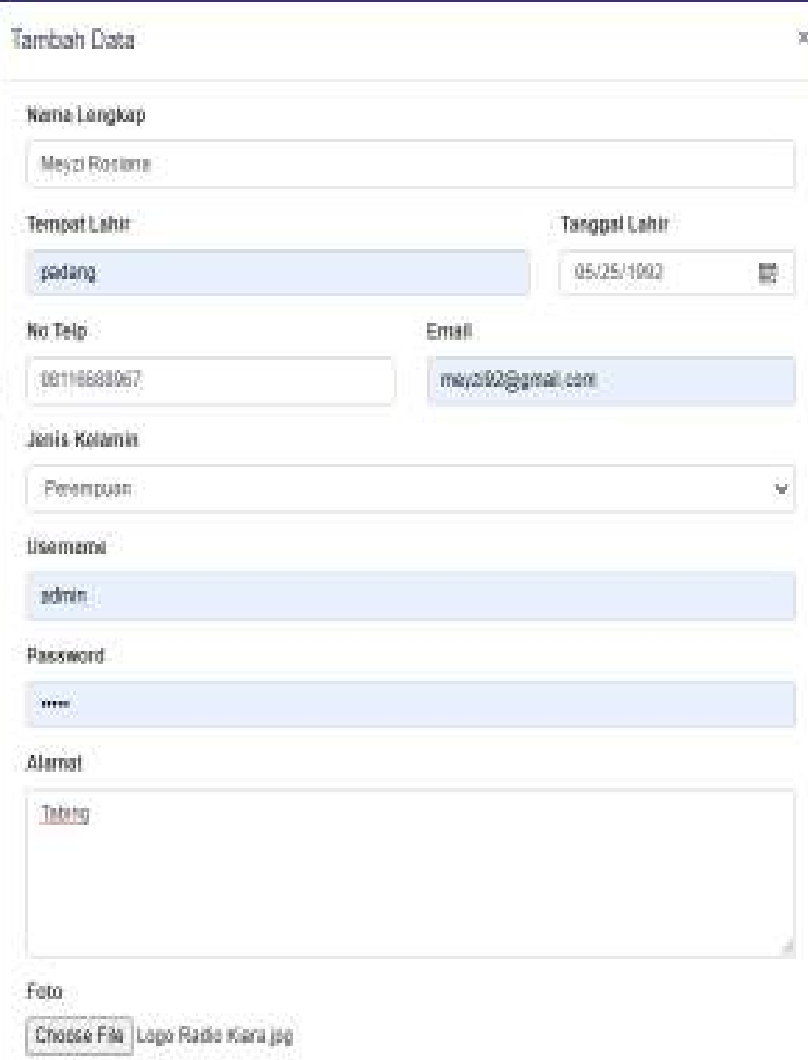

\section{Sinton}

\section{Gambar 2. Form Input Data Admin}

\section{From Data Kriteria}

Data Kriteria bertujuan untuk menjadi tolak ukur dan memudahkan dalam memberi penilaian terhadap penyiar radio. Untuk lebih jelasnya From data Kriteria dapat dilihat pada Gambar 3.

\begin{tabular}{|c|c|c|c|}
\hline \multicolumn{2}{|c|}{ Exo a o cos } & \multicolumn{2}{|l|}{$\operatorname{sen}$} \\
\hline s3 & I Hixis & Bxt & $A x$ \\
\hline 1 & at:end & es & 7 \\
\hline$\hat{\varepsilon}$ & $3<<<3$ & 15 & 8 \\
\hline$s$ & RTISARKATIS & is & 【 \\
\hline 2 & Per ellay & (1) & 【 \\
\hline 8 & idx:xstenecya & 62 & g \\
\hline 6 & keasya & 61 & 【' \\
\hline raskd & 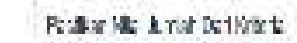 & 1 & \\
\hline
\end{tabular}

\section{Gambar 3. Form data Kriteria}

4. Form Input Penyiar Radio

Input Penyiar radio bertujuan untuk memudahkan dalam memberi penilaian terhadap penyiar radio. Untuk lebih jelas pengisian form input penyiar radio dapat dilihat pada Gambar 4.

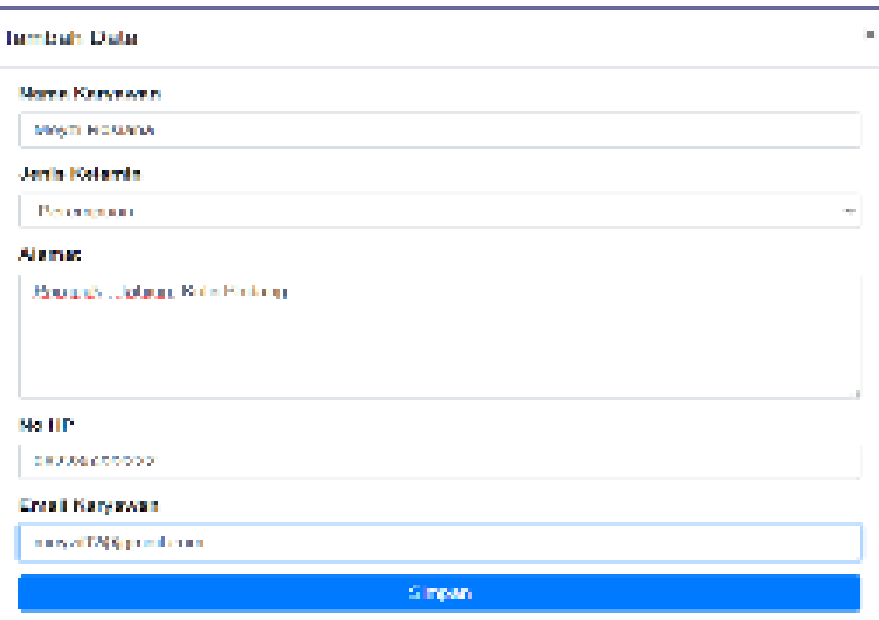

\section{Gambar 4. Form Input Penyiar}

\section{Form Input Penilaian}

Input penilaian bertujuan untuk mengisi nilai untuk penyiar radio. Untuk lebih jelas pengisian form input Penilaian dapat dilihat pada Gambar 5. 


\section{SILAHKAS IS FORM BERIKUT}

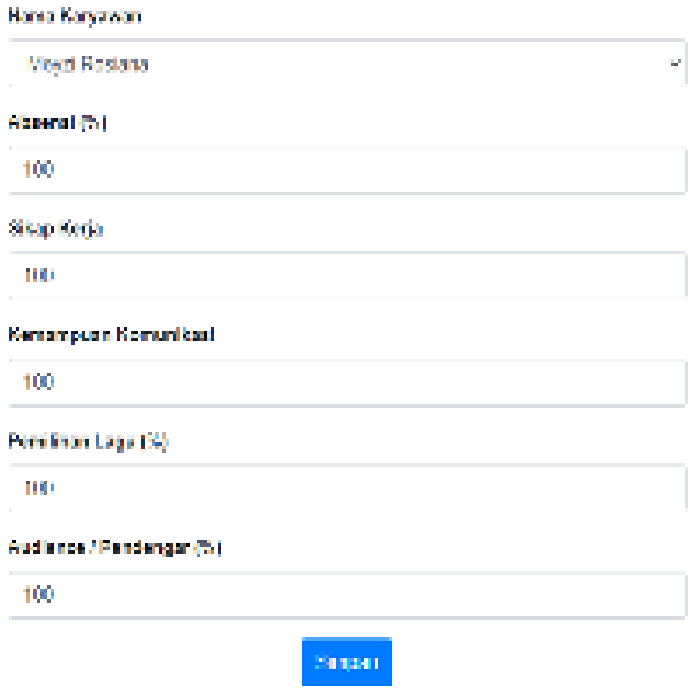

Gambar 5. Form Input Penilaian

\section{Form Hasil Perhitungan}

Berdasarkan tahap perhitungan yang telah dilakukan dan didapatkan total hasil, untuk lebih jelas dapat dilihat pada Gambar 6.

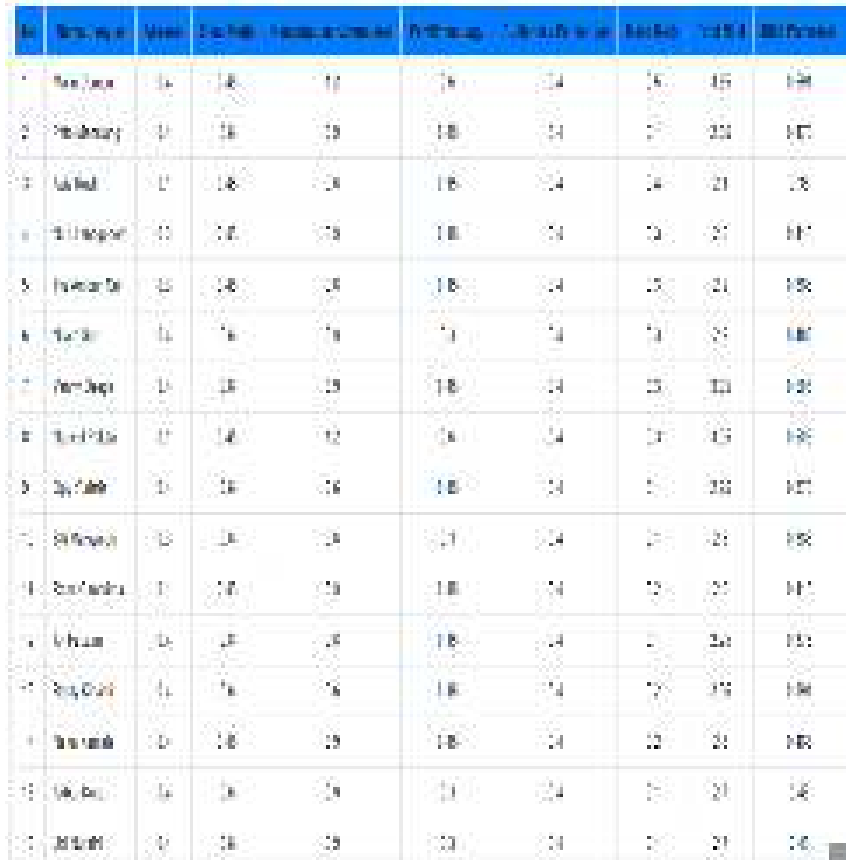

\section{Gambar 6. Form Hasil Perhitungan}

7. Form Hasil Perangkingan

Berdasarkan tahap perhitungan yang telah dilakukan dan didapatkan hasil perangkingan, untuk lebih jelas dapat dilihat pada Gambar 7.

\begin{tabular}{|c|c|c|c|c|}
\hline 4 & $t=a d$ & $=114$ & A * * tant & let \\
\hline 1 & seter & 12 & tSI & 1 \\
\hline 2 & is & $x$ & is: & : \\
\hline 1 & 2064 & th & 36 & I \\
\hline 4 & tan & $\because 4$ & 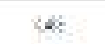 & $:$ \\
\hline$T$ & Hims: & 22 & As: & $\therefore$ \\
\hline 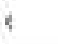 & viled & is: & w! & ; \\
\hline - & ins: & $x$ & e: & 1 \\
\hline " & stun & 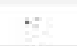 & 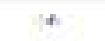 & \\
\hline 4 & hingt & is & s. & 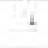 \\
\hline$\Rightarrow$ & fwiter = & is & . & 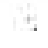 \\
\hline$t$ & secter & is & $: 8$ & 1 \\
\hline$=$ & Mnes & is & $; x$ & ; \\
\hline 4 & wes & $: 5$ & $\cdot r$ & $\therefore$ \\
\hline 4 & $7=k$ & is & $x$ & $\because$ \\
\hline s & $10 i t=0$ & $: 2$ & $\pi$ & $\because$ \\
\hline $\mathbf{x}$ & we:e & 2 & 3 & : \\
\hline
\end{tabular}

Gambar 7. Form Hasil Perangkingan

\section{SIMPULAN}

Berdasarkan hasil Penelitian yang dilakukan, maka dapat diambil beberapa kesimpulan sebagai berikut :

1. Terdapat 16 Alternatif dan 6 kriteria yang diperoleh untuk Sistem pendukung keputusan dalam pemberian reward pada penyiar radio PT Radio Kiara Indah Berjaya dengan menggunakan metode MFEP.

2. Dari hasil perangkingan menggunakan metode MFEP penyiar yang berhak menerima reward/bonus dari perusahaan adalah penyiar dengan nilai hasil evaluasi tertinggi 0,591 yaitu Malin Deman.

\section{UCAPAN TERIMAKASIH}

Penelitian ini dapat dilaksanakan dengan bantuan banyak pihak, untuk itu diucapkan terima kasih yang tidak terhingga kepada Yayasan Amal Bakti Mukmin Padang, STMIK Indonesia Padang.

\section{DAFTAR PUSTAKA}

Brata, Dwija Wisnu, and Bayu 
Whidyanto. 2017. "Sistem

Pendukung Keputusan Penentuan

Gaji Bonus Karyawan Pada Restoran

KL Express Dengan Metode

TOPSIS." Jurnal Ilmiah Teknologi

Informasi Asia 11 (1): 101. https://doi.org/10.32815/jitika.v11il. 59.

Manurung, Nuriadi. 2017. "Sistem Pendukung Keputusan Pemberian Bonus Karyawan Menggunakan Metode Ahp." Jurnal Teknologi Informasi 1 (1): 48. https://doi.org/10.36294/jurti.v1i1.42

Noviandha, Friandy Dwi, Indah Fitri Astuti, and Awang Harsa Kridalaksana. 2019. "Sistem Pendukung Keputusan Untuk Penentuan Kategori Uang Kulliah Tunggal Dengan Metode Multifactor Evaluation Process (Studi Kasus : Universitas Mulawarman)." Informatika Mulawarman : Jurnal Ilmiah Ilmu Komputer 13 (2): 88. https://doi.org/10.30872/jim.v13i2.1 552.

Rachmat Agusli1, Muhammad Iqbal Dzulhaq2, Uswatun Khasanah. 2017. "Sistem Pendukung Keputusan Pemberian Bonus Tahunan Karyawan Menggunakan Metode TOPSIS.” Sistem Pendukung Keputusan Pemberian Bonus Tahunan Karyawan Menggunakan Metode TOPSIS 1 (1): 53-58. http://jurnal.una.ac.id/index.php/jurti /article/view/42/39.

Vadreas, Andrew Kurniawan, Dwi Welly Sukma Nirad, and Nofri Aldo. 2020. "Analisa Kelayakan Tempat Pemakaman Umum Bagi Masyarakat Etnis Tionghoa Berbasis Web GIS Andrew." Indonesian Journal of Computer Science 9 no 2 (1): 11828.

https://doi.org/https://doi.org/10.330 22/ijcs.v9i2.288.

Vadreas, Andrew Kurniawan, Turaina Rifa, and Septa Ardiansyah. 2018. "Sistem Penunjang Keputusan Penentuan (Spk) Bantuan Dana Pembangunan Rumah Tidak Layak Huni (Rtlh) Dengan Metode Multi Factor Evoluation Process (Mfep)." Jurnal Teknoif 6 (1): 18-23. https://doi.org/10.21063/jtif.2018.v6. 1.18-23.

Yanto, Musli. 2021. "SISTEM PENUNJANG KEPUTUSAN DENGAN MENGGUNAKAN." Jurnal Teknologi Dan Informasi Bisnis 3 (1): 167-74.

Yunitarini, Rika. 2013. "Sistem Pendukung Keputusan Pemilihan Penyiar Radio Terbaik." Jurnal Ilmiah Mikrotek 1 (1): 43-52. https://ecoentrepreneur.trunojoyo.ac.id/jim/arti cle/download/166/163. 